Вольга Ляшчынская

Гомель

\title{
Навуковыя тэксты і фразеалагізмы
}

Увага даследчыкаў навуковага стылю беларускай мовы, як і рускай, найбольш скіравана да лексічных адзінак у сістэме моўных сродкаў перадачы навуковай інфармацыі. I гэта зразумела, бо найбольш кідкай, хоџь $і$ не адзінай асаблівасию гэтага стылю з'яўляеииа выкарыстанне тэрміналогіi ${ }^{1}$. Адносна фразеалагічных адзінак, якія усё часцей заўважаюцца ў навуковых тэкстах, маюцца толькі асобныя заўвагі, што і вызначае актуальнасць узнятага ў артыкуле пытання.

Пры гэтым традыцыйна пытанне аб выкарыстанні фразеалагічных адзінак мовы ў навуковых тэкстах разглядаецца у асноўным стылістамі пры вызначэнні характэрных прыкмет і асаблівасцей навуковага стылю сярод іншых. I тут можна адзначыць тры падыходы да гэтага пытання. Зрэдку навукойцы зайважаюць пра абмежаванае ўжыванне фразеалагічных адзінак сярод іншых моўных сродкай навуковага стылю, у прыватнасці: Уласна фразеалогія, у большасиі агульнакніжная, займае ў навуковым маўленні крайне абмежава-

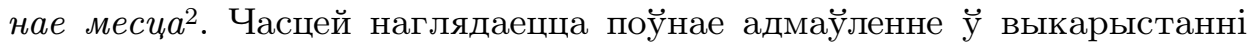
фразеалагізмаў у тэкстах навуковага стылю. Так, на думку аўтараў аднаго $з$ даследаванняў навуковага маўлення, фразеалагізмы, якія валодаюць цэласным значэннем, экспрэсіўнасцю, унутранай формай,

1 И. В. Арнольд, Стилистика современного английского языка (стилистика декодирования), Ленинград 1973, с. 69.

2 А. Н. Васильева, Практическая стилистика русского языка для иностранных студентов-филологов стариих курсов, Москва 1989, с. 67. 
якая з'яўляецца адным 3 кампанентай ix семантычнай структуры, шырокімі магчымасцямі індывідуальна-аўтарскага выкарыстання, не уัласиівь уัвогуле навуковаму стьлю $і$ нават супрацьпаказань ямуз. I нарэшце, пытанне аб фразеалагізмах як моўных сродках навуковага стылю ўвогуле абыходзіцца ўвагай. Тлумачэнне такім меркаванням крыецца ў адметнасцях функцыянальных рыс навуковага стылю, тых мэт і задач навуковай інфармацыі, якія выступаюць своеасаблівымі крытэрыямі адбору мойных адзінак у навуковых тэкстах.

У прыватнасці, адзначаецца, што навуковы стыль далёкі ад эмаиьлнальна-экспрэсіўнай афарбаванасиі. I лексіка, $i$ адбор марфалагічных формаў, $i$ характар сінтаксічных канструкщьй, $i$ парадак слоў, уласиівыля навуковаму стьлю, заклікань забяспечьць дакладнасць, лагічнасць, аб'ектыучнасць $i$ абстрактнасщь выкладу. Эмацьянальная афарбаванасць маўлення не спрыяе дасягненню гэтых мэт ${ }^{4}$. Заўважым, што даследчык не ўпамінае фразеалагізмы ўвогуле пры пераліку адзінак трох важнейшых узроўняў мовы навуковага стылю. Нават вусныля навуковыл высттуленні ў значнай ступені адчуваюиь упльуч̆ з боку кніжна-пісьмовага маўлення, таму што большасць вусных тэкстаў чьтаециа па загадзя падрыхтаванаму пісьмоваму. Такое маўленне часией за ўсё характарьзуециа манатоннасию, слабай выразнасию, адсутнасцю эмаиьянальна-экспрэсіўнай афарбоўкі ${ }^{5}$. A, як вядома, катэгарыяльнай уласцівасцю і абавязковай умовай існавання фразеалагічных адзінак з'яйляецца якраз экспрэсіӱнасць. Становіцца зразумелым, чаму фразеалагічным адзінкам мовы з такой адметнасцю сваёй афарбоўкі, адзінкам, якія якраз і вызначаюцца перавагай канатацыйнага элемента над намінатыўным, адмаўляецца ці абмяжойваецца $\ddot{y}$ выкарыстанні $\ddot{y}$ навуковых тэкстах.

Важнымі асаблівасцямі навуковага стылю лічацца абстрактнасць і абагуленасць выкладу зместу, што дасягаецца ў перавазе абстрактнай лексікі, амаль выключным выкарыстанні формаў 3-яй асобы, займенніка 1-ай асобы толькі ў форме множнага ліку, дзеясловаў цяперашняга надчасавага, ці цяперашняга пастаяннага, значэння. I ў адпаведнасці з гэтым у строга навуковым майленні выражэнне пачуццяу

3 Основы научной речи / Н. А. Буре и др., Москва 2003, с. 95.

4 А. Н. Кожин, О. А. Крылова, В. В. Одинцов, Функциональные типь русской речи, Москва 1982, с. 101.

5 У. Д. Еўтухой, Функиылянальныля стылі, [у:] Асновы культуры маўлення $i$ стыллістьикі: Вучэб. дапам. / У. В. Анічэнка, У. Д. Еўтухоў, В. А. Ляшчынская, Т. І. Тамашэвіч / пад рэд. У. В. Анічэнкі, Мінск 1992, с. 41. 
моўнымі сродкамі ўспрымаецца як адхіленне ад нормаў стылю, і адсутнасць адкрыта выражанай эмацыянальнасці ў навуковым тэксце звязана з такой яго асаблівасцю, як абмежаванасиь аўтарскага, асобаснага пачатку ${ }^{6}$. Навуковая мова пазбаўлена элементаў экспрэсіӱнасці, паколькі тут няма ўстаноўкі на наўмыснае ӱздзеянне. А фразеалагічныя адзінкі хоць і называюць і апісваюць аб'екты рэчаіснасці, але у большай ступені яны ацэньваюць месца гэтых аб'ектаў у каштоўнаснай карціне свету, характарызуюць эмацыянальна-ацэначныя адносіны носьбіта і стваральніка фразеалагізмаў. Дастакова нагадаць хаця б некалькі з ліку фразеалагізмаў-найменняў асобы ў беларускай фразеалогіi, напрыклад: абсевак у полі; божая авечка; блудны сын; ваша сястра; гог $і$ магог; ні рыба ні мяса; першы сустрэчны; сабака на сене; свежае вока; сіямскія блізняты; стары воўк; чюха-мачюха; иямия-лямия і інш., каб яшчэ раз упэўніцца, што фразеалагізмы, сапраўды, закліканы найперш для ацэнкі названай такім чынам асобы, для выражэння станоўчых ці адмоўных адносін з боку таго, хто ӱжывае гэтыя адзінкі, у адносінах да таго, каго называюць з дапамогай такіх адзінак мовы.

Дакладнасць як яшчэ адна 3 істотных асаблівасцей навуковага стылю прадугледжвае найперш адназначнасць разумення думкі, адсутнасць сэнсавых разыходжанняў паміж словам і абазначаным ім паняццем, і для навуковага стылю характэрна адсутнасць пераноснага ужывання слоў, наяўнасць метафар ${ }^{7}$. Што датычыць фразеалагізмаў, то яны як другасныя адзінкі мовы характарызуюцца трапеічнай прыродай сваёй унутранай формы, наяўнасцю вобразнага складніка, які выконвае функцыі мадыфікатара адпаведнага канцэпту, дазваляючь ажьичияуัлячь семантычную дыферэниьляиюю уัнутры поля па некалькі іншых асновах, чыл гэта магчыма з дапамогай слой у прамых значэннях (у адрозненне ад аднаслоўных метафар, якія ў гэтых адносінах не вылўляюиь прыниыповых адрозненняў ад ідыём) $)^{8}$. А гэта азначае, што выкарыстанне фразеалагізмай у навуковых тэкстах немагчыма хаця б з прычыны вобразнага патэнцыялу фразеалагізмаў як больш ком-

6 Стилистика русского языка: Учебное пособие / Сост. В. Д. Бондалетов, C. С. Bapmaneтова, Э. Н. Кушлина, Н. А. Леонова / под ред. Н. М. Шанского., Ленинград 1982, с. 203.

7 А. Н. Васильева, Курс лекиий по стилистике русского языка. Научный стиль речи, с. 85 .

8 Д. О. Добровольский, Образная составляющая в семантике идиом, «Вопросы языкознания» 1996 , № 1, с. 75 . 
плекснага і рознабаковага феномену, иым тое, што варта разумець пад мойным вобразам иі ўнутранай формай лексічнай адзінкі ${ }^{9}$.

Такім чынам, на аснове адметнасцей функцый, мэт і задач навуковых тэкстаў, іх камунікатыўных якасцей адбываецца адбор мойных сродкаў, якія складаюць сваю сістэму. Сумясціць такія паказчыкі, як эканомнасць выражэння навуковых ведаў, дакладнасць, абстрактнасць, абагуленасць, адсутнасць уздзеяння навуковай інфармацыі на чытача і у у нейкім сэнсе «збыткойнасць» семантыкі, экспрэсіўнасць, перавагу ацэначнасці над намінатыўнасцю фразеалагізмаў як знакаў з максімальна пойным семантычным наборам, кадыфікаваным у форме значэння ў выглядзе макракампанентаў, што ахопліваючь граматылку, дэнатачыю, ачэнку, матььвачьюю, эматыйнасць $і$ стылістыцную маркіраванасць не прадстаўляецца магчымым ${ }^{10}$. Вось чаму, паводле меркавання многіх і найперш стылістаў, у тэкстах навуковага стылю няма ці амаль няма месца фразеалагізмам. Але ці так гэта? Для адказу на пастаўленае пытанне, што і з'яўляецца аснойнай мэтай нашага артыкула, да якой дабаўляем вызначэнне сутнасці і зместу фразеалагічных адзінак, звернемся да характарыстыкі, з аднаго боку, фразеалагічных адзінак у іх разнавіднасцях, крытэрыях іх дыферэнцыяцыі і асновах дэфініцыі паняцця 'фразеалагізм', з другога - да тэкстаў навуковага стылю з іх рознай жанрава-стылёвай прыналежнасцю.

Навуковыя тэксты у сукупнасці складаюць змест навуковага стылю, які рэалізуецца $\ddot{y}$ чатырох падстылях: уласна навуковым (манаграфіi, артыкулы, дысертацыйныя даследаванні, аўтарэфераты, выступленні на канферэнцыях), тэхнічным (тэхнічнае апісанне апаратаў, прыбораў і да т. п.), вучэбна-навуковым (падручнікі, вучэбныя дапаможнікі, лекцыі, тлумачэнні на ўроках, практычных занятках, рэфераты і інш.) і навукова-папулярным (брашуры, лекцыі для шырокіх колаў з мэтай перадаць навуковыя веды).

Фразеалогія як асобны раздзел навукі аб мове і як сукупнасць фразеалагічных адзінак менавіта ў другой частцы свайго вызначэння да гэтага часу разглядаецца па-рознаму, ці межы фразеалогіi, паводле двух падыходаў да вырашэння гэтага пытання, вызначаюцца ў шырокім і вузкім значэнні. Так, калі фразеалогію разглядаюць у вузкім значэнні, што стала адметнасцю меркавання большасці фразеолагаў

\footnotetext{
9 Тамсама, с. 73.

10 В. Н. Телия, Русская фразеология. Семантический, прагматический и лингвокультурологический аспектьи, Москва 1996, с. 17.
} 
апошняга часу і найперш В. М. Тэліiі ${ }^{11}$, то тады яе змест складаюць толькі тыя ўстойлівыя адзінкі, якія вызначаюцца не столькі паводле такіх крытэрыяў, як узнаўляльнасць і ўстойлівасць, колькі цэласнасцю свайго значэння, унутраным сэнсавым адзінствам, якое не выцякае са значэння кожнага слова, парайн. устойлівае спалучэнне аказваць дапамогу, у якім кожнае слова захойвае сваё значэнне, і фразеалагізм, ці ідыёму, касиьмі класиіся, значэнне якой 'прыкладаць вялікія намаганні дабіцца чаго-н.' ніяк не выяўляецца i, зразумела, не ройнае суме значэнняў яе кампанентай-слоў. Калі ж фразеалогію разглядаюць у шырокім значэнні, то да фразеалагізмаў адносяць самыя розныя тыпы ўстойлівых выразаў. Па-першае, ад фразеалагізмаў да фразеалагічных спалучэнняў як аднаго з трох тыпаў фразеалагізмаў паводле сту-

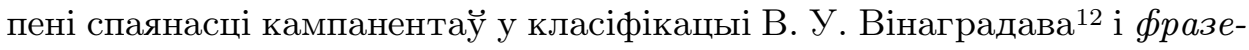
алагічных выразаў як чацвёрты тып у класіфікацыі М. М. Шанскага 13 . Па-другое, ад фразеалагізмаў да ўсіх іншых устойлівых спалучэнняу слоў, сярод якіх называюць прылказкі $і$ прылмаўкі, ці парэміi (паводле сучаснай тэрміналогіi), крылатыля словьл і афарызмы, састаўныля тэрміныл, спалучэнні слоў з фразеалагічна звязаньлм значэннем, перыцфразьл і нават иылаты [гл., напрыклад, Е. Г. Балыніну ${ }^{14}$, а таксама дапаможнікі па беларускай мове для вучня $\breve{y}^{15}$ і студэнтаўу16]. Заўважым, што $\breve{y}$ свой час М. М. Шанскі ${ }^{17}$, як і А. В. Кунін ${ }^{18}$, адносіць да

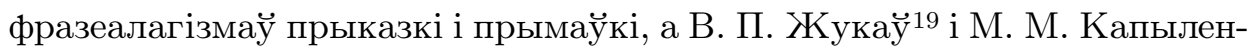
ка ${ }^{20}$ - толькі тую частку парэмій, якія ўжываюцца ў пераносным значэнні і з'яўляюцца семантычна цэласнымі і сінтаксічна нечлянімымі.

11 В. Н. Телия, Русская фразеология. Семантический, прагматический и лингвокультурологический аспекть.

12 В. В. Виноградов, Избранные труды. Лексикология и лексикография, Москва 1977.

13 Н. М. Шанский, Фразеология современного русского языка, Москва 1963, с. 44.

14 Е. Г. Балынина, В мире фразеологизмов: курс по выбору. Экспериментальное пособие для учащихся 11 классов учреждений, обеспечивающих получение общего и среднего образования, с бел. и русск. языком образования с 12-летним сроком обучения, Минск 2004, с. 6.

15 Беларуская мова: тэорыя, тэсты: для школьнікаў і абітурыентаў / Э. Д. Блінава [і інш.], Мінск 2006, с. 55.

16 Сучасная беларуская мова. Фразеалогія: практыкум / склад. А. І. Зянько, Наваполацк 2004, с. 9.

17 Н. М. Шанский, Фразеология современного русского языка, с. 44.

18 А. В. Кунин, Английская фразеология (теоретический курс), Москва 1970.

19 В. П. Жуков, Семантика фразеологических оборотов, Москва 1978.

20 М. М. Копыленко, З. Д. Попова, Очерки по общей фразеологии (фразеосочетания в системе языка), Воронеж 1989. 
Паводле сваёй сутнасці - забяспечваць захаванне навуковых ведай - навуковыя тэксты характарызуюцца цэлым шэрагам адметнасцей, з якіх найперш выдзяляецца імкненне да абсалютнай дакладнасці і адсутнасці сэнсавых разыходжанняў, адназначнасці наймення прадметаў і з'яў навуковай сферы. Зразумела, што мойныя сродкі з экспрэсіўнымі адценнямі, «семантычнымі абертонамі» (Б. А. Ларын), ці дадатковай канатацыяй альбо дадатковай канатацыйнай інфармацыяй, як часцей называюць апошнім часам, з'яўляюцца па крайняй меры непажаданымі ў навуковай мове. Што да фразеалагізмаў, то яны найперш істотна адрозніваюцца сваім значэннем ад значэння лексічных адзінак мовы 3 іх дакладнай стылістычнай дыферэнцыяй, пра што ў свой час заўважыў яшчэ Б. А. Ларын, калі пісаў, што ў мове спалучэнне слоў дае сэнс большы, чьл простая сума «значэнняў» асобных слоў 21. Пазней гэтую думку развіў В. М. Макіенка, які зазначыў: У фразеалагізма намінатыўнае растворана ў экспрэсіўныл, падпарадкавана яму. Гэтыля два бакі мойнага знака ў фразеалагізме сінкрэтычныля, тады як у лексіиь (асабліва неэкспрэсіўнай) - дыферэнчавань, раз'яд$н_{а н ы l^{22}}$. Праўда, пры гэтым звяртаем увагу на той факт, што ў сваім выказванні даследчык мае на ўвазе так званы вузкі падыход пры вызначэнні дэфініцыі паняцця фразеалагізм, ці, больш дакладна, выдзяленне $з$ агульнага масіву ўстойлівых выразаў такой іх падгрупы, як ідыёмы, значэнне якіх, - паводле В. М. Тэлія, - заўсёды больш насычана «дэталямі», чьл значэнне слова». I далей вядомая даследиыиа рускай фразеалогіi дадае, што «істотным для выканання ідыёмамі знакавай функиьі з'яўляециа $i$ падключэнне да яе як рачьянальнай ачэнкі, так $і$ ачэнкі эмачьянальнайㄹ․

Становіцца зразумелым, што выкарыстанне фразеалагізмаў (у іх лік уключаюцца фразеалагічныя адзінкі, ці фразеалагізмы, што, паводле тэрміналогіі В. У. Вінаградава, аб'ядноўваюць фразеалагічныля зрашчэнні і фразеалагічныля адзінствы) ва ўласна-навуковым і навукова-тэхнічным падстылях будзе выключэннем з правіла. Сапраўды, цяжка ўявіць у манаграфіі ці навуковым артыкуле выкарыстанне стылістычна маркіраваных фразеалагізмаў тыпу адраблячь шарварку, ку-

21 Б. А. Ларин, Эстетика слова и язык писателя. Избранные статьи, Ленинград 1974 , c. 36 .

22 В. М. Мокиенко, Славянская фразеология: учеб. пособие для вузов по спец. Рус. яз. и лит. - 2-е изд. , испр. и дополн., Москва 1989, с. 211.

23 В. Н. Телия, Русская фразеология. Семантический, прагматический и лингвокультурологический аспектьи, с. 86. 
рам на смех, лічьць варон, мазоліць вочь, як піць дащь і інш. Аднак, усё ж такі яны рэдка, але сустракаюцца, ілюстрацый чаго можа быць сказ з артыкула, прысвечанага вывучэнню дыялектнай лексікі у у мове I. Пташнікава: Сапраўдную «зялёную вуліиу» пісьменнік дае народнаму слову ў рамане «Мсиіжь» 24 . І гэта не адзіны прыклад, а ўвогуле аналіз навуковых тэкстаў дазваляе сказаць, што больш шырока фразеалагізмы такога кшталту з перавагай кніжных характэрны для тэкстай літаратуразнаўцай і гісторыкаў. Вось толькі некалькі ілюстрацый ужывання фразеалагізмаў у межах асобных сказаў, выпісаных з артыкулаў даследчыка літаратуры:

Эпісталярная спадчьна пісьменнікаў XIX стагоддзя раскрьввае невядомьяя дагэтуль рысы іх творчай індывідуальнасиі, пашьрае ўяўленне пра дыляпазон мастачкіх і прыватна-чалавечьх інтарэсаў, прьадиьняе заслону над бязлітаснай палітькай расійскай улады ў дачьненні да беларускага мастацкага слова (с. 12); Бедная беларуская мова! Косткай у горле стала яна для польскіх паноў, а з каниа XVIII стагоддзя $і$ для расійскіх чьноўнікаў. Добра разумелі янь, што там, дзе жьве мова, там ёсиь народ са сваёй памячию, чалавечай $i$ нацьянальнай годнасию, правам на незалежную, годную будучьню. Таму і рабілі ўсё магчьлме, каб падрэзащь крылль гэтаму слову на самым узлёче (с. 12); Дзённікавая форма вымагала запісаў па гарачых слядах падзей, па свежых уражаннях, з захаваннем вастрыні першаснага ўспрылмання, як, напрыклад, у запісах А. Петрашкевіча, дзе ён расказвае пра уัмовы, у якіх праходзілі этапьл ссьлльньх у Ciбір, пра жорсткія адносінь уัладьл да палітьчных выгнаннікаў $i$ інш. I тылм не менш побытавы аспект уласнага жыция ва ўсіх дзённіках застаециа на другім плане (с. 16); Мемуары Я. Лучьны пралівалі святло на ход паўстання ў Іауменскім павеце, адкрыввалі новыя імёныл... (с. 20); Сапраўды, праўда стала краевугольньим каменем яго [В. Бакава - В.Л.] эстэтычнай $i$ грамадзянскай пазічыі (с. 48); Ва ўнісон душы пісьменніиь гучалі песні жанчьн, іх аповеды пра нялёгкую долю (с. 55); Вылмушань дажьвваць апошнія гады на чужыне $\ddot{е н ~[Ф . ~ С к а р ы н а ~-~ В . Л .] ~ н а ~ в е к і ~ в е ч н ь љ я ~ в я р н у у ̆ с я ~ н а ~ р а д з і м у ~ с в а і-~}$ мі кнігамі, сваімі геніяльнылі прарочьмі ідэямі, якія жывілі не адно пакаленне беларусаў на доўгіх иярністьх скрыжалях часу (с. 62); Дьь

24 В. П. Лемцюгова, Дьялектнае слова ў кантэксце мастацкага твора, [у:] Беларускае слова ў тэксце $i$ ў сістэме мовы / Пад рэд. В. К. Шчэрбіна, Мінск 1994, c. 60 . 
i як дакажаш сваю правату, калі спекуляиья ідзе па самйм виьшэйшьм рахунку: пад сумленне ставічиа твая вернасць радзіме, партылі, камсамолу? (с. 108); Галоўна, што мей на ўвазе аўтар, - перадаџь атмасферу, каларыт часу. Як $i$ чьлм жьвве факультэт на пачатку 1950-х гадоў? На першь погляд, нічога адметнага. Берасневіч гаворыць пра такія рэчь, пра якія на поўны голас загаварыла наша літаратура, прэса, грамадскасиь літаральна на парозе новага стагоддзя; На высокай мажорнай ноче заканчваециа твор (с. 109)25.

Значна часцей фразеалагізмы адзначаюцца ў ліку іншых вобразных сродкай мовы $\breve{y}$ навукова-вучэбнай і асабліва навукова-папулярнай літаратуры, што абумойлена ўжо неабходнасцю данесці навуковую інфармацыю цікава, даступна, падкрэсліўшы адметнасць аўтарскай пазіцы, выявіўшы пры гэтым аўтарскі стыль выкладу. Прывядзём некалькі прыкладай фразеалагізмаў у складзе асобных сказай з вучэбнай літаратуры:

Калі тлумачьць літаральна, слова ў слова, дык гэта - Справа Усеагульная, інакш кажучь - Рэспубліка. Польскія магнатьи (найбагатшыл людзі) узялі уัладу ў свае рукі $i$ ў другой палове XVII cm. завалодалі ўсім палітычным жьичём на зямлі Беларусі (с. 47); У кожныл разе, запоўніць белья прагальи на карие Беларусі, дзе, можа, $i$ не ступала ў мінульля стагоддзі нага збіральнікаў фальклору, ды праліць святло на даўно знятае з карыстання слова або иэльг крьлаты выраз (с. 52); Усё рабілася “на расійскі капьл", а ў дадатак яичэ прылучалася малапісьменнасщь многіх пісараў (с. 87); Час ад часу прыгадваюиь гэты вызначальны для беларускай нацыі дакумент [«Дзяржаўная праграма развічиа беларускай мовы $і$ іншых нащьлянальных моваў у вярхойных органах, на прадпрьемствах, ва ўстановах $i$ грамадскіх арганізацьях рэспублікі» 1990 г.], але, шиьра кажучь, воз і ияпер не скранаециа з месца (с. 280) і інш. [30]; Перыляды заняпаду беларускай літаратурнай мовь прьладаюиь на XVIII cm. $i$ пачатак XIX cm., аднак ужо ў другой палове XIX cm. беларуская мова адрадзілася, як Фенікс з пеплу, на народна-дыялектнай асно-

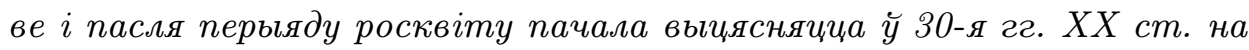
перьљферью сацьяльнага жыция беларускага грамадства (с. 50) 26.

25 Л. І. Прашковіч, Пра праву вечнасчі: Беларуская літаратура XIX-XX стагоддзяу у кантэксие часу і прасторы: Зб. навук. артыкулаў / уклад., рэдаг. і прадмова Т. С. Нуждзіна, Мінск 2009.

26 Б. А. Плотнікаў, Кароткая гісторыя беларускай мовы $і$ мовазнаўства: Вуч. дапам., Мінск 2002. 
Як ілюстрацыю тэксту 3 навукова-папулярнай літаратуры ўзгадаем змястойную і сапраўды папулярна выкладзеную навуковую інфармацыю ў брашуры «Што такое лінгвагеаграфія» А. А. Крывіцкага, адрасаваную вучням сярэдняга і старэйшага ўзросту, дзе аўтар выкарыстойвае экспрэсіўна-эмацыянальныя моўныя сродкі, сярод якіх адзначаюцца і фразеалагізмы. Напрыклад:

Нечаканья $і$, безумоўна, зусім нежаданьля вынікі вялікай, шматгадовай $і$ самаахвярнай пращьл, з якой Г. Венкер звязваў пэўныля асабістыля надзеі, маглі прьвесиі яго калі не да трагедыі, то да расчаравання. Цераспалосіиа меж пашьрэння розных дыляектных прыкмет не лезла ні уั якія «тэарэтычныя вароты», пярэчьла звыкламу строгаму парадку рэчаў $і$ нават, здавалася, элементарньм уяўленням па дыялекталогіi. I зусім натуральна, што Г. Венкер не атрылмау ні маральнай, ні матэрыляьнай падтрылкі ад Берлінскай акадэітт навук для ажыцияўлення задуманага ім атласа.

Але трэба сказаць, што Г. Венкер не ўпай у адиай (с. 33) 27.

Але нават у тэкстах навукова-папулярнага падстылю 3 найбольшай актыўнасцю фразеалагізмай іх выкарыстанне падпарадкойваецца асноўным мэтам навукова-папулярнага выкладу - давесці навуковую інфармацыю даходліва, зразумела і цікава для адпаведнага тыпу чытача.

Як відаць, выкарыстанне фразеалагізмаў у навуковых тэкстах, якія адзначаюцца ўсё ж такі ў нешматлікіх выпадках і якія можна лічыць выключэннем з агульнага правіла афармлення тэкстаў уласна навуковага і асабліва тэхнічнага падстыляў, нельга ні забараніць, ні лічыць парушэннем правіла аб іх ужыванні сярод мойных сродкай. Украпленне фразеалагізмаў у розных паводле жанрава-стылёвай прыналежнасці навуковых тэкстах, як паказвае аналіз, зусім натуральнае, бо падпарадкойваецца агульным законам і правілам моўнай канвы навуковага выкладу, а фразеалагізмы дапамагаюць падкрэсліць і адцяніць думку даследчыка, выразна выявіць яму сваю пазіцыю адносна ўзнятага пытання, прыцягнуць увагу чытача, ажывіць строгі і сухі выклад. Праўда, пры гэтым у тэкстах, што складаюць сістэму навуковага стылю, найбольш часта выкарыстоўваюцца адзінкі, у якіх пераважае выкарыстанне інтэлектуальна-эмацыянальнага, а эмацыянальна-ацэначная афарбоўка выступае дадатковай да інтэлектуальна-ацэначнай (ніжэй усякай крытылкі, трапіџь на ўрадлівую глебу, пакідае жадаџь лепшага, а воз $і$ зараз там, вылводзічь у свет, вьходзіиь у свет,

27 А. А. Крывіцкі, Што такое лінгвагеаграфія, Мінск 1986. 
добры геній, з дарагой душой, закладваџь асновьь, звяртаџь на сябе ўвагу і інш.).

На аснове адзначанага можна меркаваць, што выкарыстанне фразеалагізмаў у навуковым тэксце не складае спецыфічную адзнаку гэтай адметнай групы тэкстаў нашага часу, але дазваляе канстатаваць пранікненне элементаў эмацыянальнага, у нашым выпадку з дапамогай фразеалагізмаў, у навуковыя тэксты. Дарэчы, паводле меркавання Н. Я. Мілаванавай, у сапраўды навуковым стылі экспрэсіўнасць-эмацыянальнасць неабходная і натуральная, паколькі яна адцяняе ӱжо аргументаваную лагічную думку аўтара ${ }^{28}$. Не адмаўляе навуковаму стылю ў вобразнасці, эмацыянальнасці і ўвогуле ў экспрэсіўнасці і вядомая даследчыца пытанняў стылістыкі рускай мовы М. М. Кожына 29. Але варта заўважыць, што назначэнне элементаў эмацыянальнага i экспрэсіўнага ў навуковай мове адметнае ад, напрыклад, размойнага маўлення з яго нязмушанасцю і непасрэднасцю выражэння эмоцый ці ад мастацкай літаратуры, дзе яны служаць для стварэння мастацкага вобраза. У навуковай мове выкарыстанне экспрэсіӱна-эмацыянальнага, у прыватнасці, фразеалагізмаў, накіравана на прыцягванне ўвагі да таго, пра што выкладаецца, на тлумачэнне думкі, яе канкрэтызацыю. Праўда, трэба яшчэ ўлічваць пры гэтым такі фактар, як жанр, форма зносін - пісьмовая ці вусная, тэма, форма і сітуацыя зносін (ці адрасат, аўтар і ўзаемаадносіны паміж аўтарам і атрымальнікам інфармацыі), аўтарская індывідуальнасць і інш. У межах артыкула мы абмежаваліся аналізам тэкстаў толькі ў пісьмовай форме, але, як вядома, вуснае маўленне, напрыклад, навуковая дыскусія, гутарка, выступленне перад масавай аўдыторыяй, характарызуецца больш шырокім выкарыстаннем фразеалагізмаў, што абумоўлена як жанравай асаблівасцю такіх тэкстаў (непадрыхтаванасць, непасрэдная прысутнасць адрасата, лінейны характар пабудовы маўлення), так і індывідуальнасцю асобы аўтара, яго ўстановак, асабістай зацікаўленасці, ацэнкі таго, што ён выкладае ці паведамляе, індывідуальнай манерай (прыгадваюцца адметныя лекцы Ф. М. Янкоўскага, палемічныя выступленні А. Я. Міхневіча на навуковых канферэнцыях ці на абароне дысертацыйных даследаванняй).

28 Н. Я. Милованова, Наблюдение над средствами экспрессивности научной речи, [в:] Исследования по стилистике. Вып. 5 / Отв. ред. Л. М. Майданова, Пермь 1976, c. 142 .

29 М. Н. Кожина, Сопоставительное изучение научного стиля и некоторые тенденции его развития в период научно-технической револючии, [в:] Язьюк и стиль научной литературь / Отв. ред. М. Я. Цвиллинг, Москва 1977, с. 17. 
Аднак менавіта тэкстам навуковага стылю, у тым ліку і найперш уласна навуковым і тэхнічным, характэрна значная колькасць іншага тыпу ўстойлівых адзінак, якія да фразеалагізмаў (у вузкім значэнні дэфініцы гэтага тэрміна) не маюць ніякіх адносін, але, паводле шырокага разумення фразеалогіi, уключаюцца ў яе склад.

Такімі ўстойлівымі выразамі з'яўляюцца сродкі афармлення звязанасці, лагічнасці і адлюстравання структуры навуковага выкладу. Гэтыя ўстойлівыя адзінкі, ці тэкстаўтваральныя сродкі (тэрмін I. В. Адзінцовай) выкладу навуковай інфармацыі, служаць для фарміравання і падтрымання структуры навуковага тэксту, тым самым вызначаючы, сапраўды, яго спецыфіку: яны дапамагаюць успрыманню, паказваюць паступовасць, дакладнасць і логіку выкладу. Да такіх адносяцца пабочныя звароты, устойлівыя выразы, якія служаць:

- для ўказання на крыніцу інфармацыі (паводле думкі/меркавання/выказвання/слоў, у адпаведнасці з пазічьяй/з пунктам гледжання, як мяркуе...),

- на парадак размяшчэння аргументаў (na-nершае, na-другое, па-трэчяе, па-чачвёртае...),

- на адносіны да спосабу перадачы думкі (карачей кажучь, інакш кажучь, іншымі словамі...),

- для тлумачэння іншым спосабам (калі можна так выразічиа, дакладней кажучьи, маециа на йвазе, справа ў тьл, што...),

- для супастаўлення розных даных ці аргументаў (з аднаго боку, з другога боку, у адрозненне ад, разам з тылм, побач з гэтылм...),

- для выдзялення і засяроджвання ўвагі на пэўнай інфармацыі (пери за ўсё, у прыватнасиі, у асаблівасиі...),

- для падкрэслівання неабходнасці ці адсутнасці пэўнага дзеяння (мае сэнс, не мае сэнсу, ёсць усе падставьь/асновьь, няма падстай/ ніякіх асноў, вынікае неабходнасць, паўстае пьттанне...),

- для ўказання на часавую суаднесенасць частак выкладу ці палажэнняў, дзеяння (перш за ўсё, у першую чаргу, побач з, як было адзначана, у далейшьм, у той жа час...),

- для фармулёўкі лагічнага вываду (такім чынам, як відаџь, з разгледжана вынікае, як бачьц... $)^{30}$.

Да гэтых сродкай звязанасці навуковага маўлення далучаюцца усстойлівыя выразы для перадачы прычынна-выніковых і ўмоўна-вы-

30 Л. В. Одинцова, Текстооформляюшие языковые средства научной речи, [в:] Вопросы изучения русского языка, истории и культуры Pоссии. Bыл. 1. Russian Department. National Chengchi University, Taipei; Taiwan 1998, p. 106-108. 
ніковых адносін паміж часткамі навуковага тэксту ( $у$ сувязі з гэтылм, прыл такой умове, у такім выладку).

Выпрацойка і функцыянаванне менавіта ў навуковым стылі пералічаных тэкстайтваральных сродкай абумоўлена неабходнасцю даказваць, аргументаваць вынесеныя для абмеркавання навуковыя палажэнні, гіпотэзы, выяўляць іх прычыны і вынікі. Такія ўстойлівыя канструкцыі складаюць адметнасць выкладу навуковай інфармацыі. Яны характэрны для ўсіх падстыляў у іх жанравай разнастайнасці і складаюць адну з спецыфічных нормаў сінтаксісу навуковага стылю. Вось ілюстрацыя тэксту з ўжо цытаванай навукова-папулярнай кнігі А. А. Крывіцкага:

Аб'ектам абследавання $і$ наступнага адлюстравання Ж. Жиильерон абраў, натуральна, народную мову франчузаў. У прывватнасиі, франиузаў у межах усёи Францьі, а таксама мясиовае насельніцтва Бельгіi, Швейиарыі $i$ Італіі, мова якога з'яўляециа раманскай (дакладней кажучь, галараманскай). Зразумела, што гэта неабсяжнае мора людзей з ix iдыядыляектамі, з аднаго боку, а, з другога - акіян разнастайных мойньх $i$ дылялектных сродкаў. Патрэбны былі навукова абгрунтаваныя абмежаванні як у адньм, так $і$ у другім, якія б дазвалялі рашыць пастаўленую задачу па стварэнню дастаткова дэталёвай $i$ выразнай панарамь франиузскай народнай мовь з найменшымі вьдаткамі часу $і$ намаганняў.

Для гэтага Ж. Жилльерон распрацаваў дзве выключна важныля рэчьл для падобнага даследавання - апьттальнік і сетку абследавання.

Апьттальнік, як сведчьщъ яго назва, - гэта зборнік, дакладней, спіс пьтанняў. Кожнае пьтанне накіравана на высвятленне таго, які сродак мовь (дыллекту) характэрньл маўленню для пэўнай мэтьл. У прыватнасиі, у якія гукі уัвасабляециа пэўнае слова, як выглядае яго форма пры змяненні, якім словам называециа пэўнь прадмет,з'ява прыродыл $i$ г. д. (с. 36).

3 тэксту манаграфіі возьмем хаця б асобныя сказы, напрыклад:

I ў гэтымм ён [Б. Лесьмян, польскі паэт - В.Л.] мае рацыю (с. 13); У иэльлм працэс баладьзаџьі паэзіі будзе праяўляииа уั творчасиі згаданых $i$ іншых паэтаў па-рознаму (с. 35); I для гэтага ёсиь усе падставьи, бо нават класічная рамантычная балада, на першы погляд так далёкая ад рэальнасиі, уздымала важныя праблемь, што хвалаявалі нащью, той або іншыл кащьляльньл клас (с. 37$)^{31}$.

31 I. Ф. Штэйнер, Варожаць балады вякой: Беларуская балада і славянскія традыъиыс, Мінск 1993. 
Заўважым і яшчэ на адзін тып устойлівых адзінак, што характэрны ўсім разнавіднасцям навуковых тэкстаў: як строга навуковым тэкстам манаграфій, дысертацыйных даследаванняў, так і нават менш строгім вучэбным і папулярным навуковым тэкстам. Размова ідзе пра тэрміны, якім надаецца асноўная роля $\ddot{\mathrm{y}}$ навуковых тэкстах, бо да $25 \%$ усіх слоў навуковага тэксту складаюиь тэрміны 32 . Але 3 іх выдзелім адзін тып - састаўныя тэрміны, ці тэрміналагічныя звароты, якія абазначаюць розныя навуковыя паняцці тыпу бройнаўскі рух, метад Дэльфа, спектральныя клась, шатландская гама, эзопаўская мова і інш. і якія характэрны розным сферам навукі і тэхнікі. Тэрміналагічныя адзінкі такога тыпу валодаюць цэласнасцю логіка-паняційнага паводле характару свайго значэння і гэтым набліжаюцца да фразеалагізмаў. Ім характэрна, паводле заўвагі А. Н. Васільевай, сnеиыфічнае пралўленне «фразеалагічнасці», калі шматлікія спалучэнні аказваюича «фразеалагізмамі» для неспецьилістаў, паколькі семантыина раскрываючиа толькі ў тэрміналагічнай сістэме данай падмовы навукі ${ }^{33}$. Сапрайды, яны належаць да канкрэтнай галіны навукі і зразумелы, як правіла, спецыялістам, напрыклад, тэрміны дэльфійскі метад - метад экспертнай ацэнкі будучага; лабіялізаваныя гукі - гукі, якія артыкулююць з лабіялізацыяй; лубачная літаратура - разнастайныя па змесце выданні з малюнкамі, якія прызначаліся для шырокіх мас працойных; макаранімічная мова-мова, у якой часта сустракаюцца чужаземныя словы, выразы; сінтаксічная сувязь - сувязь слоў, якая служыць для выражэння ўзаемазалежнасці элементаў словаспалучэння і сказа; удзельная вага - адносіны вагі цела пры тэмпературы $0^{\circ} \mathrm{C}$ да вагі ройнага аб’ёму вады пры тэмпературы $4^{\circ} \mathrm{C}$; фатонная ракета - гіпатэтычная ракета 3 фатонным рэактыўным рухавіком, цяга якога ствараецца накіраваным выцяканнем фатонаў, і інш. Хаця нярэдка тэрміналагічныя спалучэнні $\ddot{y}$ самых розных галінак навукі і тэхнікі могуць узнікаць на аснове матафарызацыі, напрыклад: адамаў яблыккадык; зязюльчыны слёзы - аднагадовая або шматгадовая расліна сямейства злакавых з некалькімі сцябламі і суквеццем мяцёлкай; анюціны вочкі - травяністая трохколерная расліна сямейства фіялкавых (viola trikolor) i інш. Наяўнасць у іх складзе хоць бы аднаго метафарычнага

32 Г. Я. Солганик, Т. С. Дроняева, Стилистика и культура речи русского языка: учеб. пособие для студентов учреждений выси. проф. образования, 6-е изд., испр., Москва 2012, с. 12.

33 А. Н. Васильева, Практическая стилистика русского языка для иностранных студентов-филологов старших курсов. - 2-е изд., перераб, с. 67. 
элемента, слова з фразеалагічна звязаным значэннем, дазваляе іх называць «метафарызаванымі тэрміналагічнымі спалучэннямі», але тым не менш гэта не фразеалагізмы, бо яны адрозніваюцца ад фразеалагізмаў дакладнасцю, адназначнасцю, адсутнасцю канатацый.

Іншая справа, калі $\ddot{\mathrm{y}}$ выніку дэтэрміналагізацыі тэрмінаў пэўных галін навукі, наадварот, узнікаюць фразеалагізмы, пра якія мы ужжо пісалі ${ }^{34}$ і якія ў навуковых тэкстах, у прыватнасці, у тэкстах мовазнаўцаў, выступаюць як аб'ект вывучэння ці як ілюстрацыя навуковых палажэнняў. Напрыклад, на аснове эканамічных тэрмінаў утвораны фразеалагізмы акиьі падаюиь 'чые-н. шансы на поспехі ці значэнне, уплыў каго-н. зніжаюцца'; акцыі паднімаюича/павышаюича 'чые-н. шансы на поспехі ці значэнне, уплыў каго-н. узрастаюць'; залаты фонд 'самае лепшае, самае каштойнае, самае значнае'; спісваць з рахунку 1) 'лічыць застарэлым, забываць'; 2) 'адхіляць каго-н., лічачы непрыдатным да якой-н. дзейнасці'; cnicваць у тыраж 'адхіляць каго-н., лічачы непрыдатным да якой-н. дзейнасці'; у ажуры 1) 'добра, паспяхова, удала, як і павінна быць'; 2) 'паспяховы, удалы, такі, як і павінны быць' і інш.

Такім чынам, фразеалагізмы $\ddot{y}$ ix вузкім дэфініцыйным вызначэнні не з'яўляюцца актыўным моўным сродкам навуковых тэкстаў, але і не забараняюцца для ӱжывання $\ddot{y}$ розных жанрах, тыпах навуковага стылю. Пры гэтым іх ужыванне не складае адметнай рысы навуковых тэкстаў, бо падпарадкоўваецца асноўным задачам адлюстравання навуковай інфармацыі. Праўда, актыўнасць выкарыстання фразеалагізмаў (= ідыёмаў) заўважна ўзрастае ад уласна навуковага да навукова-папулярнага падстылю і ў залежнасці ад пісьмовай формы да вуснай. Ад фразеалагізмаў, асноўным крытэрыем вызначэння якіх з'яўляецца цэласнасць значэння, трэба адрозніваць устойлівыя адзінкі іншага тыпу, у прыватнасці, 1) сістэму структурных, ці тэкстаўтваральных, сродкаў звязанасці, афармлення выкладу навуковай інфармацыі $\ddot{y}$ іх дыферэнцыяцыі паводле месца і ролі выкарыстання і 2) састаўныя тэрміны. Менавіта гэтыя дзве групы ўстойлівых адзінак якраз і выяўляюць адметнасць тэкстаў незалежна ад іх жанравай разнастайнасці і ўваходзяць у сістэму адметных моўных сродкай навуковага стылю.

34 М. У. Буракова, В. А. Ляшчынская, Анамастыка, тэрміналогія $і$ фразеалогія: вучэб.-метад. дапам., Мінск 2011, с. 106-127. 


\section{S T R E S Z C Z E N I E}

\section{TEKSTY NAUKOWE I FRAZEOLOGIZMY}

W artykule omówiono zastosowanie frazeologizmów w tekstach naukowych. Wskazano przede wszystkim na konieczność odróżniania pojęć „jednostka frazeologiczna" i „utarty zwrot”, gdzie ten ostatni z natury zbliżony jest do jednostki frazeologicznej lecz nie jest z nią tożsamy. Następnie omówiono rolę powyższych jednostek leksykalnych w strukturze tekstu naukowego. Z jednej strony, mimo że częstotliwość występowania jednostek frazeologicznych w różnych pod względem gatunku tekstach naukowych jest odmienna, należy podkreślić ich dyskretną rolę jako środka zabarwienia emocjonalnego w nowoczesnym tekście naukowym. Z drugiej strony, należy podkreślić konieczność stosowania zwrotów złożonych i dobrze rozbudowanego systemu środków tekstotwórczych naukowej składni bez konieczności różnicowania tekstów naukowych według ich przynależności gatunkowej.

Słowa kluczowe: jednostka frazeologiczna, idiom, utarty zwrot, środki tekstotwórcze, pojęcia złożone.

\section{S U M M A R Y}

\section{SCIENTIFIC TEXTS AND PHRASEOLOGICAL UNITS}

The article deals with the problem of phraseological units in scientific texts. Firstly, it argues the necessity of differentiation between the notions "phraseological unit" and "set expressions", the latter being close to phraseological units in nature, but not altogether the same. Secondly, it describes the roles that the aforenamed lexical units play in the structure of scientific texts: on the one hand, though the frequency of occurrence of phraseological units in scientific texts of various genres is varied, one should stress their generally inconspicuous part as a means of adding emotional coloring to modern scientific style; on the other hand, one should point out the necessity of use of compound terms and a well-developed system of text-building means of scientific syntax without differentiating scientific texts according to their genres.

Key words: phraseological unit, idiom, set expressions, text forming means, compound terms. 